\title{
FEDERAL INCOME TAXATION OF SUPPORT PAYMENTS UNDER POSTDIVORCE ORIGINAL AGREEMENTS
}

Changing judicial interpretations of the alimony and support-maintenance provisions of the Internal Revenue Code, ${ }^{1}$ coupled with a congressional failure to indicate their intended interrelationship, render uncertain the tax consequences of payments made pursuant to an agreement, first entered into after divorce, to support a former spouse. Section $215^{2}$ of the Code provides that a husband ${ }^{3}$ may deduct payments if they are taxable to his wife. Section 71(a) prescribes the conditions under which payments are includible in the wife's gross income: Under subsection (1), the parties must be separated under a final decree of divorce or legal separation, ${ }^{5}$ while the payments ${ }^{8}$ must

1. INT. Rev. CoDE of 1954, $\S \$ 7,215$ (formerly Int. Rev. Code of 1939, $\S \S 22(\mathrm{k})$, 23(u), added by ch. 619, §§ 120 (a)-(b), 56 Stat. 816-17 (1942)).

2. INT. Rev. CODE of 1954, § 215 (a):

General Rule-In the case of a husband described in seetion 71 , there shall be allowed as a deduction amounts includible under section 71 in the gross income of his wife, payment of which is made within the husband's taxable year. No deduction shall be allowed under the preceding sentence with respect to any payment if, by reason of section $71(d)$ or 682 , the amount thereof is not includible in the husband's gross income.

3. INT. Rev. CoDE of 1954, $\$ 7701$ (a) (17) (formerly Int. Rev. Code of 1939, $\S 3797$ (a) (17), added by ch. 619, $\$ 171$ (f), 56 Stat. 818 (1942), as amended, ch. 210, $\$ 10(\mathrm{i})$, 58 Stat. 240 (1944)) provides that "wherever appropriate to the meaning of [the] . . . sections, the term 'wife' shall be read 'former wife' and the term 'husband' shall be read 'former husband'; and ... the term 'husband' shall be read 'wife' and the term 'wife' shall be read "husband." The terms are similarly so used throughout this Note.

4. INT. Rev. CODE of 1954, § 71 (a) (1):

Decree of divorce or separate maintenance-If a wife is divorced or legally separated from her husband under a decree of divorce or of separate maintenance, the wife's gross income includes periodic payments (whether or not made at regular intervals) received after such decree in discharge of (or attributable to property transferred, in trust or otherwise, in discharge of) a legal obligation which, because of the marital or family relationship, is imposed on or incurred by the husband under the decree or under a written instrument incident to such divorce or separation.

5. While a decree is required, it need not be valid in the state in which one of the parties lives. Feinberg v. Commissioner, 198 F.2d 260 (3d Cir. 1952), reversing 10 T.C. 1485 (1951) (out-of-state divorce held null and void in the state of domicile); G.C.Mr. 25250, 1947-2 Cuar. BuLL. 32 (unenforceable Mexican divorce sufficient).

Deduction for alimony pendente lite was denied under the 1939 Code which did not contain present $\$ \S 71$ (a) (2) or (3). Wick v. Commissioner, 161 F.2d 732 (3d Cir. 1947), affirming per curiam, 7 T.C. 723 (1946) (part of the payments under consideration vere made pursuant to an oral agreement, the balance were made because of a court order for alimony pendente lite) ; Joseph A. Fields, 14 T.C. 1202 (1950), off'd on assother issuc, 189 F.2d 950 (2d Cir. 1951) (court order to pay alimony pendente lite in a separation proceeding); Treas. Reg. 11.1, $\$ 39.22(\mathrm{k})-1(\mathrm{a})$ (1943). Similarly, payments ordered by: 
be periodic, ${ }^{7}$ received subsequent to the decree, ${ }^{8}$ in discharge of a legal obliga-

interlocutory decree or support order were held nondeductible. Commissioner v. Evans, 211 F.2d 378 (10th Cir. 1954), affirming 19 T.C. 1102 (1953) (interlocutory decree); Frank J. Kalchthaler, 7 T.C. 625 (1946) (support order). Under the 1954 Code, payments made pursuant to a court order for support entered after March 1, 1954, are now deductible under section 7l(a)(3). See note 15 infra. The Final Regulations specifically provide for the deductibility of alimony pendente lite and payments made under an interlocutory decree. Treas. Reg. § 1.71-1(b) (3) (i) (1957).

Deductions for support payments pursuant to separation agreements, without divorce or legal separation, were also denied under the 1939 Code. Terrell v. Commissioner, 179 F.2d 838 (7th Cir.), cert. denied, 340 U.S. 822 (1950) (deduction denied even though a court had ordered enforcement of the agreement); Smith v. Commissioner, 168 F.2d 446 (2d Cir. 1948) (deduction for payments pursuant to a written separation agreement denied despite the fact that such an agreement might be equivalent to a legal separation in the state in which it was executed) ; see Joseph C. Brightbill, 18 P-H Tax Ct. Mem. 83, aff'd per curiam, 178 F.2d 404 (3d Cir. 1949). Under $\$ 71$ (a) (2), written separation agreements executed after August 16, 1954, now give rise to deductions. Sec notes 12 and 14 infra.

6. The alimony or separate maintenance sections of the Internal Revenue Code provide "rules for treatment in certain cases of payments in the nature of or in licul of alimony or an allowance for support as between spouses who are divorced or separated." Treas. Reg. \$ 1.71-1(a) (1957) (formerly Treas. Reg. \$ 29.22(k)-1(a) (1942)) (Emphasis added.) ; see H.R. REp. No. 2333, 77th Cong., 2d Sess. 46, 71-72 (1942) ; S. Rep. No. 1631, 77th Cong., 2d Sess. 84 (1942). Thus, it has been held that the payments need not be considered alimony under the local law so long as they are periodic and otherwise satisfy the statute. United States v. Soltermann, 163 F. Supp. 397 (N.D. Cal. 1958) (deduction allowed though money designated as payment for property rights); Brown $v$. United States, 121 F. Supp. 106 (N.D. Cal. 1954); see Burton v. United States, 139 F. Supp. 121 (D. Utah 1956).

7. Lump sum payments do not qualify for the support deduction. H.R. REP. No. 2333, 77th Cong., 2d Sess. 46 (1942); Pappenheimer v. Allen, 164 F.2d 428 (5th Cir. 1947), affirming 71 F. Supp. 788 (D. Ga. 1947) ; Arthur B. Baer, 16 T.C. 1418 (1951), rov'd on other grounds, 196 F.2d 646 (8th Cir. 1952).

"Periodic payments" are not defined in the Code, although it is stated that they are not installment payments (those which discharge a part of a specified principal sum). INT. REv. CODE of 1954, $\$ 7.1$ (c)(1). The judiciary has interpreted periodic payments as sums paid at intervals (though they need not be regular intervals) which are indefinite as to amount or duration; whereas, installment payments are periodic sums, paid in cqual or unequal amounts, as "portions of a definite and established whole." Herbert v. Riddell, 103 F. Supp. 369, 387 (S.D. Cal. 1952); see Baker v. Commissioner, 205 F.2d 369, 370 (2d Cir. 1953); John H. Lee, 10 T.C. 834, 836 (1948).

Installment payments which are "to be paid or may be paid over a period ... [of] more than ten years" are treated as periodic to the extent of the amount paid in any one year limited by $10 \%$ of the principal sum. INT. REv. Cope of 1954, $\S 71$ (c) (2). While advance installment payments are allocable to the year in which received and subject to the $10 \%$ limitation, $i b i d$., delinquent installment payments are excepted, sec Treas. Reg. § $1.71-1$ (d) (2) (1957) (formerly Treas. Reg. 118, $\$ 39.22(\mathrm{k})-1(\mathrm{c})$ (1953)); Holahan v. Commissioner, 222 F.2d 82 (2d Cir. 1955), affirming 21 T.C. 451 (1954); Grant v. Commissioner, 209 F.2d 430 (2d Cir. 1953), affirming 18 T.C. 1013 (1952); Gale v. Commissioner, 191 F.2d 79 (2d Cir. 1951), affirming 13 T.C. 661 (1949). It is therefore possible for a husband to avoid the inhibition of the $10 \%$ limitation through the judicious manipulation of arrearages.

Payments which are expressly or impliedly subject to such contingencies as death, 
tion arising out of the marital or family relationship, ${ }^{0}$ and imposed ${ }^{10}$ by the decree or a written instrument ${ }^{11}$ incident to the divorce or separation. Under subsection (2), 12 the parties must be merely "separated,"13 while the pay-

remarriage, or variation in economic status have been held to be periodic. Roland Kieth Young, 10 T.C. 724 (1948) (alimony might vary with the husband's income); Balker v. Commissioner, 205 F.2d 369 (2d Cir. 1953), reversing 17 T.C. 1610 (1952) (first accepted the general contingency doctrine); Myers v. Commissioner, 212 F.2d 448 (9th Cir. 1954), reversing $11 \mathrm{CCH}$ Tax $\mathrm{Ct}$. Mem. 1163 (1952) (contingency of death, not allowed for in agreement, read into six-year alimony provision); Prewett v. Commissioner, 22l F.2d 250 (8th Cir. 1955), reversing 22 T.C. 270 (1954) (alimony payments for two years contingent upon no remarriage or material change in husband's income during the period). The Treasury, accepting the contingency doctrine, has extended it to include contingencies set forth in the terms of the decree, instrument or agreement or imposed by local law. Treas. Reg. \$1.71-1(d) (3) (1957) ; Rev. Rul. 59-45, 1959 Isr. Rev. Bur. No. 5, at 73 (specifically citing, accepting, and applying 1 yyers and Prewett to $\$ \S 71(a)(1)-(3))$. Therefore, local law, in direct contradiction of the congressional command of uniformity, sce note 18 infra, can be a matter of federal tax consequences.

8. Thus payments made prior to the granting of a decree of divorce or separation and payments in the absence of a decree have been denied deductibility. Charles $L$. Brown, 7 T.C. 715 (1946); Abraham L. Berman, 16 P-H Tax Ct. Mem. 1133 (1947).

The effect of this rule is not mitigated by a subsequent nume pro tume order which validates the payments. Peter Van Vlaanderen, 10 T.C. 706 (1948), aff'd, 175 F.2d 389 (3d Cir. 1949) ; Robert L. Daine, 9 T.C. 47 (1947), aff'd, $16 S$ F.2d 449 (2d Cir. 1948).

9. See H.R. Rep. No. 2333, 77th Cong., 2d Sess. 71 (1942), 1942-2 Cuas. BuLL. 372, 428; S. REP. No. 1631, 77th Cong., 2d Sess. 84 (1942), 1942-2 Cusr. Bull 504, 5GS.

10. See Smith v. Commissioner, 168 F.2d 446 (2d Cir. 1948) (obligation to p3y not imposed by a court decree, and therefore not incident to divorce or separation). Thus, voluntary payments have been denied deductibility though the other requirements of the statute were fulfilled. George R. Joslyn, 23 T.C. 126, 133-34 (1954), modified on other issues, 230 F.2d 871 (7th Cir. 1956); Dale E. Sharp, 15 T.C. 185 (1950) : Ben Aryerson, 10 T.C. 729 (1948) (oral agreement not enforceable by state law); Frederick S. Dauwalter, 9 T.C. 580 (1947) (voluntary payments upon request of wife).

11. A formal agreement has not been required, however; informal correspondence establishing an agreement has been held sufficient. Charles Campbell, 15 T.C. 355 (1950) (letter held sufficient); Floyd W. Jefferson, 13 T.C. 1092 (1949), acq., 1950-1 Cuss. Bulc. 3 (oral agreement confirmed by letters prior to divorce). But see Fredericls S. Dauwaiter, 9 T.C. 580, 585 (1947) (court held that informal correspondence was not tantamount to a "written instrument"). The court has recently gone so far as to permit an oral agreement made prior to divorce which is later the basis of a postdivoree written agreement. Maurice Fixler, 25 T.C. 1313 (1956).

12. INT. Rev. CoDE of 1954, § 71(a) (2):

Written separation agreement.-If a wife is separated from her husband and there is a written separation agreement executed aiter the date of the enactment of this title, the wife's gross income includes periodic payments (whether or not made at regular intervals) received after such agreement is exceuted which are made under such agreement and because of the marital or family relationship (or which are attributable to property transferred, in trust or otherwise, under such agreement and because of such relationship). This paragraph shall not apply if the husband and wife make a single return jointly.

13. The parties must also file individual returns. See text of $\S 71(a)(2)$, note 12 sitpra. 
ments must be periodic, made because of the marital or family relationship, received subsequent to a written separation agreement executed after August $16,1954,{ }^{14}$ and incurred under such an agreement. Subsection (3) ${ }^{15}$ applies whenever a wife is separated from her husband, and they are filing individual returns, but the payments must be imposed by a judicial decree of support or maintenance. ${ }^{16}$

These provisions reversed the tax treatment of alimony and support payments, which had previously been considered nondeductible personal expenses. ${ }^{17}$ They were passed to relieve the payor of an unreasonable financial burden, to tax the person actually benefiting from the payments, and to achieve tax uniformity "regardless of variance in the laws of different States." ${ }^{18}$ In 1942, the present section 71 (a) (1) was enacted. ${ }^{10}$ The applica-

14. Section $71(a)(2)$ covers agreements "executed after the date of the enactment of this title ..." The Regulations clarify the date intended. Treas. Reg. $\S 1.71-1(b)$ (2) (i) (1957).

15. INT. REv. CODE of 1954, § 71(a) (3):

Decree for support.-If a wife is separated from her husband, the wife's gross income includes periodic payments (whether or not made at regular intervals) received by her after the date of the enactment of this title from her husband under a decree entered after March 1,1954, requiring the husband to make the payments for her support or maintenance. This paragraph shall not apply if the husband and wife make a single return jointly.

16. There is a double date limitation under this subsection. The Code requircs that the payments be made pursuant to a decree enacted after March 1, 1954, and that such payments be received "after the date of the enactment of this title." Treas. Reg. $\S 1.71-1$ (b) (3) (i) (1957) fix the latter date as August 16, 1954.

17. They were deemed payments in discharge of a general obligation to stupport imposed on a spouse. Helvering v. Fitch, 309 U.S. 149 (1940); Douglas v. Willcuts, 296 U.S. 1 (1935); Gould v. Gould, 245 U.S. 151 (1917); see Princess Lida of Thum \& Taxis, 37 B.T.A. 41 (1938). But cf. Helvering v. Fuller, 310 U.S. 69, 74-75 (1940).

A husband could sometimes avoid being taxed on these payments by use of an alimony trust. But the problems of control, see Lorenz Iversen, 3 T.C. 756 (1944) ; Louis Stockstrom, 3 T.C. 255 (1944), reversion, see Lillian R. Chertoff, 6 T.C. 266 (1946), fluctulation in income, Mahana v. United States, $115 \mathrm{Ct}$. Cl. 716, $88 \mathrm{~F}$. Supp. 285, cerl. denicd. 339 U.S. 978 (1950), and differences in local law, Calvin HI. Sugg, 1 T.C. 431 (1943); Walter L. Ferris, 1 T.C. 992 (1943), made this device uncertain at best, sec Comment, 66 YALE L.J. 881 (1957). An alternative method lay in a lump-sum trausfer of property which would finally and absolutely discharge the support obligation. Helvering v. Fuller, 310 U.S. 69 (1940). The efficacy of this approach depended, however, on local law, the ex-wife's cooperation, and the husband's financial resources. See Bitrker, Federal INCOMe Estate aNd Gift Taxation 171-72 (2d ed. 1958).

18. S. REp. No. 1631, 77th Cong., 2d Sess. 84 (1942), 1942-2 Cun. Bull. 504, 568, further stating:

These amendments are intended to treat such payments as income to the spotse actually receiving or actually entitled to receive them and to relicve the other spouse from the tax burden upon whatever part of the amount of such payments is under the present law includible in his gross income. In addition, the amended sections will produce uniformity in the treatment of amounts paid in the nature of 
tion of the deduction was restricted, ${ }^{20}$ presumably because the unavailability of the joint return ${ }^{21}$ to married couples made exploitation of the support deduction to achieve excessive income splitting advantages a temptation. While the current Code extends deductibility to payments made under written separation agreements between separated spouses (section $71(a)(2)$ ) and court orders for support (section 71 (a)(3)),, 22 no explicit provision is made for support payments made pursuant to postdivorce original agreements. ${ }^{23}$ Moreover, vagaries of case law obfuscate the tax position of such payments under the existing statute. Nonetheless, these payments, when made because of the severed marital relationship, would seem to be esjuden generis with the section 71 transactions.

If the support payments are made pursuant to a divorce or separation decree ${ }^{24}$ or to a written instrument which is incorporated in a decree, ${ }^{25}$ and are periodic, they are clearly within subsection (1) of section 71(a). But incorporation is not a prerequisite to deductibility. Support payments may derive from a written separation agreement not incorporated in a court decree, which, in turn, makes no provision for support. ${ }^{20}$ It is then necessary to deal with the troublesome problems of whether the instrument is "incident" to divorce or separation and whether the payments are in discharge of a "legal obligation" arising out of the marital or family relationship. ${ }^{27}$

or in lieu of alimony regardless of variance in the laws of different States concerning the existence and continuance of an obligation to pay alimony.

Ibid.; accord, H.R. REP. No. 2333, 77th Cong., 2d Sess. 46, $71-72$ (1942), 1942-2 Cuss. BuLl. 372, 409, 427.

19. Int. Rev. Code of $1939, \S \S 22(\mathrm{k}), 23(\mathrm{u})$, added by ch. $619, \S \S 120(\mathrm{a}),(\mathrm{b}), 56$ Stat. 816-17 (1942).

INT. REV. CODE of $1954, \S 71$, applies only to post-1954 agreements and decrees. S. REp. No. 1622, 83d Cong., 2d Sess. 10, 171 (1954). The present $\S 71(a)(1)$ is equivalent to the old $\S 22(\mathrm{k})$, as is $\S 215$ to $\S 23(\mathrm{u})$.

20. For the restrictions, see note 5 sipra.

21. Under the joint return privilege, available since 1948 , the husband has been permitted to attribute one-half of his and his wife's combined income to his wife. Int. Rev. Code of 1939, $\S 12(d), 51(b)$, as amended, ch. 168, 62 Stat. 110, 114-16 (1948) (now INT. REv. CODE OF 1954, §§ 2, 6013).

22. Interlocutory decrees and alimony pendente lite are specifically covered by the Final Regulations. Treas. Reg. § 1.71-1(b) (3) (i) (1957).

23. As used in this Note, "postdivorce original agreement" reiers to an agreement for support payments entered for the first time after divorce or separation, which does not amend or modify preexisting arrangements.

24. See John A. Isfalt, 24 T.C. 497 (1955); George R. Joslyn, 23 T.C. 126 (1954), modified on other issues, 230 F.2d.871 (7th Cir. 1956) ; Clark J. Baker, 23 T.C. 161 (1954): Frank J. Loverin, 10 T.C. 406 (1948).

25. See Commissioner v. Blum, 187 F.2d 177 (7th Cir. 1951) ; Margaret O. White, 24 T.C. 452 (1955) ; Elsie B. Gale, 13 T.C. 661 (1949), affd, 191 F.2d 79 (2d Cir. 1951); Warren Leslie, Jr., 10 T.C. 807 (1948).

26. Jessie L. Fry, 13 T.C. 658 (1949); Tuckie G. Hesse, 7 T.C. 700 (1946).

27. The requirements of "legal obligation" and "incidence," while functionally interrelated, are separate and should be so considered; however, courts in treating this aspect 
The "incidence" requirement has been subjected to a continuous process of judicial explication characterized by a transition from narrow construction to liberality. In early cases, the Tax Court interpreted "incidence" to require positive proof that the parties jointly contemplated divorce or legal separation at the time they made the agreement. ${ }^{28}$ The easiest way to show contemplation was to make the agreement contingent on divorce. ${ }^{20}$ But the fear that an agreement expressly contingent might be declared invalid as encouraging dissolution of the marital relationship, and the divorce voided or denied for collusion, prompted cautious draftsmen to omit contingency provisions. ${ }^{30}$ It thus became necessary, as a practical matter, to show mutually coexistent intent by means of extrinsic evidence. ${ }^{31}$ In later cases the circuit courts specifically denied the necessity of contemplation or anticipation, ${ }^{32}$ holding that a finding

of $\S 71$ (a) (1) are not rigorous in their separation nor clear in their interpretation of the terms.

28. E.g., Frances Hamer Johnson, 21 T.C. 371 (1953) ; Floyd W. Jefferson, 13 T.C. 1092 (1949) ; Estate of Daniel G. Reid, 15 T.C. 573 (1950), aff'd on other groumds, 193 F.2d 625 (2d Cir. 1952); Jessie L. Fry, 13 T.C. 658 (1949); Joseph J. Lerner, 15 T.C. 379 (1950), rev'd, 195 F.2d 296 (2d Cir. 1952).

29. For examples of separation agreements made contingent on divorce, see Maric M. Newman, 26 T.C. 717 (1956), aff'd 248 F.2d 473 (8th Cir. 1957); Tillie Blum, 10 T.C. 1131 (1948), rev'd on other grounds, 187 F.2d 177 (7th Cir. 1951).

30. There is some basis for this fear. E.g., Griffiths v. Griffiths, 69 N.J. Eq. 689, 60 Att. 1090 (Ch. 1905) (petition for divorce denied because of collusion in that there was evidence of an agreement to pay a lump sum, provided the wife obtain a divorce); Shechan v. Sheehan, 77 N.J. Eq. 411, 77 Atl. 1063 (Ch. 1910) (agrcement to bring suit for divorce with husband to pay wife's legal expenses held collusive); Kilborn v. Field, 78 $\mathrm{Pa} .194$ (1875) (agreement not to oppose divorce in rettrn for an agreed sum held void); see Vayette v. Myers, 303 IIl. 562, 136 N.E. 467 (1922), cerl. deticd, 260 U.S. 749 (1923) (agreement not to defend is void as against public policy); Roberts v. Roberts, 206 Misc. 779, 134 N.Y.S.2d 877 (Sup. Ct. 1954).

But, this attitude need not completely exclude predivorce alimony arrangcments. It has been held that an agreement to settle alimony claims so long as it is for a fair consideration, established at a reasonable amount, and otherwise free of collusion, is not inimical to public policy, and is therefore valid. Dennison v. Dennison, 98 N.J. Eq. 230, 130 Atl. 463 (Ch. 1925) ; Miller v. Miller, 284 Pa. 414, 131 Atl. 236 (1925); Estate of Frank, 195 Pa. 26, 45 Atl. 489 (1900); Alverson v. Alverson, 249 S.W.2d 472 (Mo. Ct. App. 1952) ; see Hemingway v. Ball, 118 N.J. Eq. 378, 380, 179 Atl. 374, 375 (Ch. 1935) ; Moore v. Moore, 197 Tenn. 360, 273 S.W.2d 148 (1954).

31. Intent was shown by letters exchanged by the parties or their attorneys containing references to a prospective divorce. Floyd W. Jefferson, 13 T.C. 1092 (1949) (letters between the parties discussing the impending divorce); Tuckie G. Hesse, 7 T.C. 700, 703 (1946) (letter between attorneys).

32. The courts' reasons were that (1) the requirement was unreasonable due to the potential problem of collusion, (2) the parties' state of mind during this cmotional period was not susceptible to rational proof, and (3) the written instrument recuirement was designed sufficiently to insure adequate proof of intent. Commissioner v. Miller, 199 F.2d 597 (9th Cir. 1952), reversing 16 T.C. 1010 (1951) (agreement to survive divorce, filed and approved by the court, held "incident" over wife's claim that she did not consider the possibility of divorce); Feinberg v. Commissioner, 198 F.2d 260 (3d Cir, 1952), revcrsing 16 T.C. 1485 (1951) (divorce followed four months after agreement which provided 
of "incidence" did not necessitate proof of the intent of either party but simply" some connection with divorce. ${ }^{33}$ Thus the fact that an agreement was followed within a reasonable time by divorce ${ }^{34}$ has been held sufficient to make the instrument incident thereto. ${ }^{35}$ Although recent decisions have held that the requirements of "incidence" are satisfied by a more attenuated connection with divorce, the chronological juxtaposition of agreement and divorce remains significant. Deductions based on payments made pursuant to a postdivorce original agreement have been denied on the ground that the agreement must be executed prior to or at the time of the divorce-that is, incident to the decree of divorce. ${ }^{36}$ So long as "incidence" is interpreted this way, payments under postdivorce agreements not amendatory of predivorce agreements are necessarily not deductible.

The concept of "incidence" has been further liberalized, however, in cases of postdivorce modifications of predivorce agreements. Rigid adherence to the requirement that an alimony agreement precede or coincide with divorce would make payments under these modifications, as well as payments under postdivorce original agreements, nondeductible. But, more recently, "incident to such divorce" has been held to mean incident to the decree or the status of divorce. $^{37}$ Thus, it is no longer essential to the incidence requirement that all deductible support arrangements be concluded at the time of the divorce, so long as the adjustment is made while the parties are divorced. Although these opinions have concerned modifications of predivorce agreements, their broad

for payments in lieu of alimony and for incorporation in a subsequent divorce decree, held "incident" over wife's claim that she tried to defeat the action, that the conditions precedent had not been fulfilled, and that the consideration of the possibility of divorce at a future unspecified date was not equivalent to contemplation); Lerner v. Commissioner, 195 F.2d 296 (2d Cir. 1952), rezersing 15 T.C. 379 (1950) (separation agreement to survive divorce, divorce followed a year later, agreement not incorporated in divorce decree making no allowance for alimony, held incident).

33. Holt v. Commissioner, 226 F.2d 757, 758 (2d Cir. 1955), resersing 23 T.C. 469 (1954) ("It is . . . immaterial whether the husband and the wife or either of them intend that the agreement shall be "incident to the divorce." ").

34. Stewart v. Rothensies, 114 F. Supp. 497 (E.D. Pa. 1953); Estate of Daniel G. Reid, 15 T.C. 573 (1950); Helen Scott Fairbanks, 15 T.C. 62 (1950); Tuchie G. Hesse, 7 T.C. 700,703 (1946) (divorce proceedings instituted three days after execution of the agreement) ; Miahana v. United States, 115 Ct. C1. 716, 88 F. Supp. 285, ccrt. denicd, 339 U.S. 978 (1950) (interval of nineteen days).

35. It has also been held that if an agreement was filed and approved by the court, the statutory requirement of incidence is satisfied. Commissioner v. Aliller, 199 F.2d 597 (9th Cir. 1952), reversing 16 T.C. 1010 (1951).

36. See Commissioner v. Walsh, 183 F.2d 803 (D.C. Cir. 1950), offirming 11 T.C. 1093 (1948) ; Cox v. Commissioner, 176 F.2d 226 (3d Cir. 1949), affirming 10 T.C. 955 (1948); Commissioner v. Murray, 174 F.2d 816 (2d Cir. 1949); Smith v. Commissioner, 168 F.2d 446 (2d Cir. 1948) ; Frederick S. Dauwalter, 9 T.C. 580 (1947).

37. Hollander v. Commissioner, 248 F.2d 523 (9th Cir. 1957), recersing 26 T.C. 827 (1956) ; Newton v. Pedrick, 212 F.2d 357 (2d Cir. 1954), reiersisg 115 F. Supp. 368 (S.D.N.Y. 1953) ; Smith v. Commissioner, 192 F.2d 841 (1st Cir.), affirming 16 T.C. 639 (1951) ; Alice L. Heath, 30 T.C. 339 (1958); Raoul Walsh, 21 T.C. 1063 (1954). 
language could be applied to postdivorce original agreements. ${ }^{88}$ And the Treasury apparently has accepted the extension of "incidence" to "status" without limitation. ${ }^{39}$

The "legal obligation" language of section 71 (a) (1),,$^{40}$ on the other hand, would seem, on its face, to extend to any contractual obligation ${ }^{41}$ assumed because of the marital or family relationship. ${ }^{42}$ But courts in their attempt to interpret congressional intent have required that the contractual obligation be incurred by the husband at a time when he has a legal obligation to stipport. ${ }^{4 a}$ Since the duty to support always exists prior to divorce, ${ }^{44}$ no problem is encountered in cases solely concerned with predivorce agreements. ${ }^{46}$ But postdivorce modifications ${ }^{46}$ of predivorce agreements, the halfway house between

38. For examples of the use of broad language, see Newton v. Pedrick, supra note 37, at 360-61 ; Smith v. Commissioner, stipra note 37, at 844; Raoul Walsh, supra note 37, at 1071.

39. See Treas. Reg. $\$ 1.71-1$ (b) (1) (i) (1957) ; Treas. Reg. $\$ 1.71-1$ (b) (6) (2) (1057); Treas. Reg. $\S 1.71-1$ (c) (4) (1957); Rev. Rul. 59-45, 1959 INT. Rev. Bull. No. 5, at 73; Rev. Rul. 58-451, 1958-2 Cum. Burc. 914; Rev. Rul. 58-152, 1958-1 Cum. Bull. 32.

40. For text of $\S 71$ (a) (1), see note 4 supra.

41. See Ben Myerson, 10 T.C. 729,733 (1948); Frederick S. Dauwalter, 9 T.C. 580 (1947).

42. "Legal obligation" is not satisfied simply because the husband is legally obligated. Thus, in instances involving business payments or loan repayments, the requisite "legal obligation" was not found: the payments failed since they were not made "becatuse of the marital relationship." Campbell v. Lake, 220 F.2d 341 (5th Cir. 1955) (property settlement) ; Landa v. Commissioner, 211 F.2d 46 (D.C. Cir. 1954) (loan repayment); Thorness v. United States, 1 Am. Fed. Tax R.2d 974 (D. Ill. 1958) (business relationship); Miriam Finley Schwartz, 23 P-H Tax Ct. Mem. 160 (1954) (wife's share of damages recovered by a jointly owned business).

43. See Cox v. Commissioner, 176 F.2d 226 (3d Cir. 1949), affirming 10 T.C. 955 (1948) (divorce terminated the duty to support; hence, postdivorce agreement was not in recog. nition of an "obligation to support") ; Maurice Fixler, 25 T.C. 1313, 1314-15 (1956) (predivorce oral agreement maintained support obligation after divorce; hence, stbscquent agreement was executed while the husband "was still under ... . [a support] obligation pursuant to Illinois Law"). See also Floyd H. Brown, 16 T.C. 623, 631 (1951); Floyd W. Jefferson, 13 T.C. 1092, 1098 (1949) ; Thomas E. Hogg, 13 T.C. 361, 367 (1949).

44. 3 Vernier, American Fanily Laws $\$$ 161-62 (1935); Lindey, Separation Agreements and Antenuptial Contracts $\S 15$ (1) (1953, Supp. 1957); 3 Nelson, DiVORCE AND ANNULMENT $\$ 32.09$ (1945).

45. The courts do not concern themselves with whether the payments would be required under local law. Tuckie G. Hesse, 7 T.C. 700 (1946) (though the divorce decree did not allow the wife to receive alimony, the Tax Court held payments received purstant to a written separation agreement includible in the wife's gross income); see Floyd H. Brown, 16 T.C. 623 (1951) (deduction allowed although no duty to support after divorce under Louisiana law was shown); Thomas E. Hogg, 13 T.C. 361 (1949) (deductions allowed although support payments are not imposed by Texas law) ; cf. Laughlin's Estate v. Cornmissioner, 167 F.2d 828 (9th Cir. 1948), acq., G.C.M. 25999, 1949-1 Cust. Bull. 116 (payments out of husband's estate where there was neither a statutory nor comtnon law duty).

46. The availability of modification is essential for fulfillment of the purpose of alimony. 2 VERNIER, op. cit. supra note 44, \$§ 104, 106; Comment, 39 Micr. L. Rrv. 120. $128-30$ (1940). 
pre- and postdivorce agreements, present a doctrinal difficulty; a legal obligation to furnish additional support does not appear to exist at the time of the modification. The basis for a solution was laid in Smith $v$. Commissioner, where the "legal obligation" requirement was held satisfied by a finding that the original agreement created a continuing obligation ${ }^{48}$-thus, in effect, "legal obligation" was transferred from the original agreement to the modification. Although the underlying agreement was incorporated, the broad language of the opinion expressly declares that the agreement, not the decree, maintains the "legal obligation." 49 The potentialities of Smith were fully realized in Newton $v$. Pedrick, ${ }^{50}$ where increased payments under a postdivorce unincorporated modification of an unincorporated predivorce agreement were held deductible. The Second Circuit found that the new agreement was but "reshufflings of the ... original divorce arrangements,"51 and thus carried out a legal obligation, and went on to hold that "a subsequent adjustment of that obligation ... is 'incident to such divorce' within the purview of the statute."32

It is thus clear that, at this stage in the development of the law, payments made under all revisions of predivorce agreements will be held deductible by the husband by application of the "status" concept of "incidence" and the continuing obligation concept of "legal obligation," or simply by transference of both "incidence" and "legal obligation" from the original agreement.

Under section 71 (a) (1), so construed, what tax treatment will be accorded support payments under an original postdivorce agreement, when the divorce decree makes no provision for support or for reopening the decree for that purpose? In view of the general development of the law, it is quite possible that a court will employ the "status" 63 concept to satisfy the requirement of "incidence." A finding of "legal obligation" is more difficult. Thus, Cor $v$. Commissioner, 54 after ruling that "local alimony laws become irrelevant,"

47. 192 F.2d 841 (1st Cir.), affirming 16 T.C. 639 (1951).

48. $192 \mathrm{~F} .2 \mathrm{~d}$ at 844.

49. Ibid.

50. 212 F.2d 357 (2d Cir. 1954), reversing 115 F. Supp. 368 (S.D.N.Y. 1953).

51. 212 F.2d at 360 .

52. Id. at $361-62$.

The lower court, holding that the new agreement was wholly separate from the old, and that the additional payments were not to "carry out a legal obligation" but rather were consideration for custody of a child, sustained the Commissioner in disallowing the deduction. 115 F. Supp. 368 (S.D.N.Y. 1953). Judge Harlan, for the court of appeals, said that since an unincorporated agreement could be modified by a later court order, he saw "no ... reason why an 'unincorporated' agreement which is incident to a divorec, and which otherwise meets the requirements of the statute, cannot be modified by a subsequent 'unincorporated' agreement." 212 F.2d at 361.

53. See notes 37-39 supra and accompanying text.

54. 176 F.2d 226 (3d Cir. 1949), affirming 10 T.C. 955 (1948). See also Frederick S. Dauwalter, 9 T.C. 580 (1947) (support payments after divorce not pursuant to a proper decree or agreement held voluntary because the support obligation had been terminated): Emanuel Alboum, $10 \mathrm{CCH}$ Tax Ct. Mfern. 300 (1951) (support agreement exceuted is years after divorce held not "incident" citing and following Cox and Dameraller).

55. 176 F.2d at 229. 
held that an agreement made eight months after a divorce decree was not in discharge of an obligation to support. In those states which allow their courts to order support payments subsequent to a divorce decree which did not provide for alimony, ${ }^{56}$ however, the obligation could be found in the possibility of a locally imposed duty of maintenance. Although such a disposition would fulfill the original objectives of relieving one spouse of an unreasonable financial burden, while taxing the other, it fails to attain the goal of uniform taxation of support payments, independent of state law. ${ }^{67}$ The opposite result would obtain in those states in which divorce terminates any obligation to support if the decree did not provide for alimony. ${ }^{88}$ There, a present obligation does not exist, since local law does not recognize one; a continuing obligation cannot exist, since the husband never paid alimony. A further extension of deductibility to postdivorce original agreements, whether or not local law is applied, is unlikely.

Commentators, however, have suggested that, with the enactment of section 71 (a) (2) in 1954, problems raised by "incidence" and "legal obligation" are

56. See Il.L. REv. Stat. ch. 40, $\$ 19$ (1957) ("Irrespective of whether the court has or has not in its decree made an order for the payment of alimony or support, it may at any time after the entry of a decree ... make such order for alimony and maintenance of the spouse ... as ... shall be fit, reasonable and just...."); LA. CIv. CODE ANs. art. 160 (West 1952) ("If the wife who has obtained the divorce has not sufficient means for her maintenance, the Court may allow her in its discretion ... alimony ...."); Mass. ANN. LAws ch. 208, §34 (1955) ("upon petition at any time after a divorce, the court may decree alimony to the wife"); N.J. STAT. ANN. $\$ 2 A: 34-23$ (1952) ("Pending any matrimonial action ... or after judgment of divorce . . . the court may make such order as to . . . alimony or maintenance ... as . . shall [be] ... fit, reasonable, and just ....").

57. See note 18 sitpra.

... Congress was aware of the ... tax consequences [which] ... followed upon the intervention of local laws, with the happenstance of residency determining the identity of the taxpayer on the alimony-income.

... Congress intended to afford relief from the unfairness of the pre-existing situation to citizens of different States. ... The purpose of the Section . . . cannot be accorded its full effect were we to heed the petitioner's suggestion that, in the case of an agreement subsequent to the absolute divorce, his tax liability must be viewed in light of the possibility that, despite the divorce, there exists under State law a requirement that he continue to support his former wife.

Cox v. Commissioner, 176 F.2d 226, 229 (3d Cir. 1949).

58. E.g., Hall v. Hall, 141 Ga. 361, 80 S.E. 992 (1914) ("After a wife has obtained a decree of total divorce the matrimonial relation no longer exists, and therefore she can not then obtain an order or judgment requiring her former husband to pay alimony.").

The majority of States provide that alimony decrees may be subsequently modified. E.g., ME. Rev. Stat. Ann. ch. 166, § 63 (1954) ("the court . . may at any time alter, amend, or suspend a decree for alimony") ; Mo. ANN. Stat. $\$ 452.070$ (1952) ("The court ... may make such alteration, from time to time, as to the allowance of alimony and maintenance as may be proper ...."). But such "modification" is not available if no alimony" was granted in the original decree. Plummer v. Plummer, 137 Me. 39, 14 A.2d 705 (1940); Smith v. Sm:th, 350 Mo. 104, 164 S.W.2d 921 (1942). 
eliminated ${ }^{59}$ and that deductions for support payments pursuant to all agreements will henceforth be allowed. Subsection (2) ${ }^{60}$ applies to periodic payments made "because of the marital or family relationship under a written separation agreement ... if [the] ... wife is separated from her husband" at the time the payments are made. ${ }^{01}$ Under this subsection, a decree, "legal obligation," and "incidence" are unnecessary. Since the congressional debates and reports do not define the operational limits of section $71(a)(2)$, and, since no significant cases have arisen under the new provision, its scope has not been delineated.

May it be applied to payments made after, as well as before, divorce? If the word "separated" in the statutory phrase "if a wife is separated from her husband" is read to mean "physically living apart" regardless of whether or not there has been a divorce or legal separation, ${ }^{02}$ then section 71 (a)(1) would become totally inoperative. The foundation for such a reading, in cases of subsection (1) transactions entered by couples whose support arrangements were formerly governed by subsection (2), has been established by the final regulations, which provide that "if the wife is divorced or legally separated subsequent to the written separation agreement, payments made under such agreement continue to fall within the provisions of section 71(a)(2)."03 In further support of a unitary reading, section 7701 on "Definitions" provides in subsection (17) that "as used in [section] $71 \ldots$ if the husband and wife therein referred to are divorced, wherever appropriate to the meaning of such [section], the term 'wife' shall be read 'former wife' and the term 'husband' shall be read 'former husband." "64 The reasons for extending section 71 (a) (2) to include cases where there has been a subsequent divorce are understandable. By hypothesis, since the separation agreement was executed during marriage, the "incidence" and "legal obligation" requirements are satisfied. It would be inviting confusion and litigation to say that once divorce has occurred 71 (a) (2) becomes inoperative and the deductibility of the payments must then be tested by the standards of 71 (a) (1).

But these compelling reasons for extending the coverage of subsection (2) do not apply to postdivorce original agreements, since after divorce the hus-

59. See Powell, Separation and Divorce: Income, Gifl and Eslofe Ta.r Consequenecs, N.Y.U. 15tr Inst. on Fed. TAX 763, 773 (1957); Horne, Tax Piffalls in Allimony and Separation Payments, 35 Taxes 751, 752 (1957); MfcDonald, Tax Aspects of Divarce, Separation, Alinony, and Support, 17 U. PITr. L. REv. 1, 6-7 (1955) ; Note, 8 IV. Rrs. L. Rev. 517, 520 (1957); Note, 9 S.C.L.Q. 263 (1957). Contra, 5 Alertens, Fereral I:*co:ae Taxation, \& 31A.02 n.33 (1956); 68 HaRv. L. Rev. 372, 374 (1954).

60. See note 12 supra.

61. As is pointed out in Treas. Reg. 1.71-1(b) (6) (2) (1957), the parties need not be separated at the time of execution of the agreement.

62. See Note, 9 S.C.L.Q. 263, 265-67 (1957).

63. Treas. Reg. $\$ 1.71-1$ (b) (2) (i) (1957).

In addition, regulation $\S 1.71-1$ (b) (2) (ii) provides that a material modification of a prior agreement is sufficient to bring the payments under $\$ 71$ (a)(2) provided that the change takes place after August 16, 1954.

64. INT. REv. CODE OF 1954 § 7701 (a) (17). 
band is not always obliged to provide support. "Legal obligation" would thus be evaded via 71.(a) (2), rather than hypothetically satisfied. Subsection (2) was presumably included in the Code because separated but still-married parties could obtain favorable tax results through a joint return, unless their estrangement prevented the cooperation necessary so to file. Subsection (2) would then grant a tax advantage to the hostilely separated. Since a divorced couple cannot use the joint return, postdivorce original agreements would not be included under this rationale. In addition, the last sentence of 71 (a) (2) provides that the parties must not file a joint return, which may imply that the section is applicable only if the couple could file a joint return-that is, are not already divorced or legally separated. Finally, if Congress had intended that "separated" include all cases where the parties are physically living apart, it would have been a simple matter expressly so to provide, ${ }^{05}$ and it would have been unnecessary to retain section 71 (a) (1). ${ }^{00}$ For these reasons, courts would do violence to the statute as a whole to bypass 71(a) (1) entirely and hold payments under postdivorce original agreements deductible under subsection (2). The requirements of the former therefore retain their force in cases involving postdivorce original agreements, so that the deductibility of payments made thereunder will continue to be improbable.

But underlying legislative goals of national uniformity and taxation of the actual beneficiary point to the conclusion that all court-decreed or muttually agreed-upon support payments to divorced or separated wives should be deductible by the husband and taxable to the wife. Restricted deductibility might have been meaningful when income-splitting opportunities were unavailable to the still-married. But the 1948 joint return provisions, ${ }^{87}$ which allow a husband to attribute half his income to his wife, remove the possibility that divorce or separation will afford such an added tax advantage. In fact, quite the contrary is true, since section 71 requires that the wife actually receive the benefit of payments. Moreover, the inhibitions of section 71 (a) (1) have resulted in fortuitously diverse tax treatment of similarly situated parties.

Extension of the section 71 deduction to cover payments pursuant to support agreements entered for the first time after clivorce and not amendatory of a predivorce agreement would also be the logical fulfillment of the legislative, judicial, and administrative liberalization of conditions for deductibility. Under sections $71(a)(1)$ and (2), support payments made prior or subse-

65. The statute could have read: "If a wife is separated or divorced from her husband," or "if a wife or ex-wife is separated from her husband." See Note, 9 S.C.L.Q. 263, 266-67 (1957).

66. In post-1954 cases involving pre-1954 agreements, courts could look to the 1939 Code and cases thereunder. See Hollander v. Commissioner, 248 F.2d 523 (9th Cir. 1957), reversing 26 T.C. 827 (1956) ; Holt v. Commissioner, 226 F.2d 757 (2d Cir. 1955), recersing 23 T.C. 469 (1954) ; Alice L. Heath, 30 T.C. 339 (1958) ; Albert J. Faber, 29 T.C. 1095 (1958) ; Alan E. Ashcraft, Jr., 28 T.C. 356 (1957).

67. Rev. Act of 1948, ch. 168, $\S \S 301,303,62$ Stat. 114 (now INT. Rev. CodE of 1954, $\S \S 2,6013)$. 
quent to a divorce and pursuant to a written separation agreement entered before divorce are within the statute regardless of the terms of the agreement or the rights and duties of the parties existing at the time of execution. Agreements falling within these sections generally may be freely modified before and after divorce to provide for increased payments without regard to the amount or reason for the increase. ${ }^{88}$ Since most modifications, including those after divorce, constitute a voluntary reshuffling of the previously established obligation, it is difficult to distinguish the resulting payments from those made under an original postdivorce agreement. ${ }^{69}$ At present, all arrangements for support-maintenance, whether imposed by decree of divorce or separation, written instruments incident to divorce or separation, written separation agreements, court orders, or modifications of any of the above, will give rise to a deduction. But payments pursuant to postdivorce original agreements are denied favorable tax treatment. ${ }^{\text {To }}$

Legislative extension of deductibility to include payments under postdivorce original agreements also has practical advantages outweighing any imagined shortcomings. The suggested change is not a giveaway program; for the extended inclusion is small. The loss in tax revenue will be minor when compared with losses attendant upon passage of the joint-return provisions. Charges that such an extension will encourage extramarital financial obligations are answered by retention of the requirements that payments be for support and arise out of the family relationship, assuring that those made for independent reasons-such as business settlements, blachmail, recourtship expenses-will be excluded. The fear of tax manipulation by the payor is disproportionate to the danger, since effectuation of meaningful tax savings would require the confidential cooperation of an estranged spouse. Moreover, the present provisions holding nondeductible lump-sum payments made at once or in installments totaling less than ten years duration, ${ }^{71}$ if properly

68. See Joslyn v. Commissioner, 230 F.2d 871 (7th Cir. 1956), modifying 23 T.C. 126 (1954); Newton v. Pedrick, 212 F.2d 357 (2d Cir. 1954), reversing 115 F. Supp. $36 \mathrm{~S}$ (S.D.N.Y. 1953) ; Gale v. Commissioner, 191 F.2d 79, (2d Cir. 1951), offirming 13 T.C. 661 (1949).

Decreased payments are also allowed and account is taken of them. This would be true even if the modification was not recognized because the basis for deductions, which is derived from the incidence of taxation, is the amount actually receized by the wife.

69. Cf. Muriel Dodge Neeman, 13 T.C. 397 (1949), aff'd per curiam, 200 F.2d 560 (2d Cir. 1952), cert. denied, 345 U.S. 956 (1953) (new agreement made three days priur to divorce treated as a modification of a six-year-old separation agreement).

70. Payments claimed to be within the statute because of a state mune pro lune order are also disallowed. Van Vlaanderen v. Commissioner, 175 F.2d 389 (3d Cir. 1949), affirming 10 T.C. 705 (1948), Daine v. Commissioner, 168 F.2d 449 (2d Cir. 1948), affirming 9 T.C. 47 (1947).

71. INT. REv. CODE of 1954, § 71 (c) ; see note 7 supra. It has been suggested that lump sum payments were excluded from tax relief to prevent the husband from massing his deductions in periods of high income and to avoid a sharp depletion of a principal sum. 
administered, ${ }^{72}$ would prevent large transfers ${ }^{73}$-in the nature of property settlements-necessary for significant reductions in a husband's tax bracket. Finally, fear of manipulation in this limited area is inconsistent with the present laissez faire attitude toward increased payments pursuant to postdivorce modifications of predivorce agreements.

The practical virtues of the proposed change lie in simplicity and certainty. Determinants of tax liability will be relatively unambiguous and tax consequences predictable, thus informing the parties of the precise implications of

the income and corpus of which are expected to provide future maintenance for the dependent wife. 53 Columr. L. Rev. 1015, 1017 (1953). But cases holding that instailment payments which are expressly or impliedly subject to contingencies are periodic, have effectively repealed the lump sum limitation. See note 7 supra.

72. Perhaps the distinction, effectively repealed by the "contingency" doctrine, sec note 7 supra, between "periodic" payments, which are fully deductible, and "installment" payments, deductible only to the extent of $10 \%$ should be abandoned. Both over-concentrated deductions by the husband and over-concentrated income to the wife could be avoided if all payments whose proposed schedule, regardless of contingencies, is to run for less than ten years, were spread both as to deduction and taxable income over a ten year period. Thus, the husband would be able to deduct each year the amount actually paid, limited by $10 \%$ of the principal sum, or, if no predetermined principal sum exists, $10 \%$ of the total so far paid. In order to ensure that the recipient is able to spread her income over the ten-year period, and that she pays taxes on the same amount that her husband will deduct, her tax could be calculated in the following manner: She would pay a tax on the total amount of money actually received, when it is received. The rate of this tax would be in accordance with the rates for that year at the income bracket of the amount reccived or $10 \%$ of the total intended payments, whichever is the smaller. The total "alinony and support tax" would be the determined rate times the amount of money reccived. In this manner, the wife will pay at a rate which will not penalize her if she receives an amount greater than $10 \%$ in one year and which is geared to equal division among the years, and at the same time, the wife will pay tax on the full amount she receives, when she receives it. Thus, if the plan calls for ten yearly payments of $\$ 10,000$, and if in the first ycar she receives $\$ 50,000$, she will immediately pay the tax on $\$ 10,000$ multiplied by 5 . The government's loss of revenue resulting from her paying tax on 5 times $\$ 10,000$, rather thant on $\$ 50,000$ is illusory, since in the instant year, the husband can deduct only $\$ 10,000$, and therefore will pay tax, presumably at a higher bracket than the wife's, on the other $\$ 40,000$. Of course, there will be loss of revenue due to the wife's lower tax bracket, but this would be no different if she actually received $\$ 10,000$ each year.

When, as would usually be the case, the wife had other income, she might be taxed at the rate determined by the amount of her other income plus the amount of alimony allocable to that year (10\% of the principal sum, or actual receipts, whichever is smaller). In this manner, she would pay at the same rate as other citizens with the same income, just as if she received the alimony in other payments. If, however, in any year she reccived in alimony an amount larger than $10 \%$, she would pay "alimony tax" (at the rate for $10 \%$ times the amount received) plus an "aggregate tax" (at the rate for her other income plus allocable alimony). An adjustment would be made by giving her, in that year, a credit for her prepaid tax (functionally similar to a withholding tax) equal to allocable alimony for one year. In each subsequent year, she would be given another $10 \%$ credit until her credit is exhausted.

73. If the $10 \%$ limitation on deductions operated in all instances, little incentive for a taxpayer would exist, in a period of high income, to make a large immediate payment. 
their support agreements. In addition, it is probably unrealistic and unfair in individual cases to require that parties anticipate their future needs and resources prior to the dissolution of marriage. Divorce is often followed by appreciable changes in the financial circumstances of one or both spouses. Allowing deductions pursuant to postdivorce original agreements will permit parties to determine support arrangements at a time when they can realistically assess their respective needs and resources. Section 71 should be revised expressly to extend to all court-decreed and mutually agreed-upon bona fide support payments. 